\title{
Contractual Wages and the Wage Cushion under Different Bargaining Settings
}

\author{
Ana Rute Cardoso, IZA Bonn, University of Minho, \\ and $C E P R$
}

\section{Pedro Portugal, Banco de Portugal, Universidade NOVA de Lisboa, and IZA Bonn}

\begin{abstract}
How does a typically European bargaining system, with collective bargaining and national minimum wage, coexist with low unemployment and high wage flexibility? A unique data set on workers, firms, and collective bargaining contracts in Portugal is used to analyze the determinants of both the contractual wage and the wage cushion (difference between contractual and actual wages). The results indicate that the wage cushion stretches the returns to worker and firm attributes, whereas it shrinks the returns to union power. Therefore, firm-specific arrangements partly offset collective bargaining, granting firms certain freedom when setting wages. Contractual wages reflect trade unions' egalitarian policy.
\end{abstract}

Part of this work was carried out while A. Cardoso was visiting the Bank of Portugal, whose support is gratefully acknowledged. We thank Yoram Weiss for steering us so helpfully over the revision of this article, and Olivier Blanchard, Daniel Hamermesh, Steinar Holden, Alexandru Voicu, the participants in seminars held at Universidade NOVA de Lisboa, IZA Bonn, Tinbergen Institute, and the LoWER network (Milan), and two anonymous referees for very helpful suggestions on earlier versions of the article. We are grateful to the Ministry of Employment, Statistics Department, for access to the data used in this article. Lucena Vieira provided excellent research assistance. The usual disclaimer applies. Contact the corresponding author, Ana Rute Cardoso, at cardoso@iza.org.

[Journal of Labor Economics, 2005, vol. 23, no. 4]

(C) 2005 by The University of Chicago. All rights reserved. 0734-306X/2005/2304-0007\$10.00 


\section{Introduction}

It has been extensively argued that labor market rigidities lead to unemployment. The major line of reasoning states that, under wage rigidity, negative shocks in the labor market will translate into adjustments of the employment level, thus generating unemployment. European collective bargaining institutions, therefore, have a poor reputation since national minimum wages and minimum wages set by collective bargaining for different categories of workers can be sources of wage rigidity.

However, finer analysis suggests that the impact of labor market institutions on macroeconomic performance depends crucially on the degree of centralization or coordination in the bargaining process. Nickell (1997) points out that a high level of coordination among employers in the bargaining process may lead to lower wage settlements and lower unemployment. Calmfors and Driffill (1988) highlight that highly centralized or highly decentralized bargaining systems lead to lower unemployment, whereas intermediate levels of centralization lead to the worst outcome. Teulings and Hartog (1998) claim that more centralized wagesetting systems can be efficiency enhancing. For Portugal, Hartog, Pereira, and Vieira (2002) found that the level at which bargaining takes place has a significant impact on the wage distribution and on the returns to worker and firm attributes, and evidence on The Netherlands points in the same direction (Hartog, Leuven, and Teulings 2002). The impact of collective bargaining on the wage structure, wage rigidity, and labor market performance is, therefore, not clear-cut.

The case of Portugal can shed interesting new light on this issue. The country is pointed out as one of the Organisation for Economic Cooperation and Development (OECD) economies with the highest wage flexibility (OECD 1992), and it has one of the lowest unemployment rates in the European Union, despite having typically European labor market institutions: collective bargaining is widespread, setting the wages for unionized as well as nonunionized workers; once a collective agreement is signed, extension mechanisms can widen its coverage, voluntarily to employers or trade unions who had initially not signed the agreement or by government mandatory decision, irrespective of the workers' union membership status; a national minimum wage is enforced.

The aim of this article is to answer the questions: What degree of freedom do employers have when manipulating wages in this regulated institutional setting? How does a regulated institutional framework in the labor market coexist with a low unemployment rate and high wage flexibility? What is the impact of collective bargaining on the wage distribution?

Two novel aspects are introduced in the analysis of this topic. First of all, we rely on a micro data set that matches information on workers, 
firms, and collective bargaining contracts for over 2 million workers, 200,000 firms, 500 collective bargaining agreements, and 30,000 worker categories in collective bargaining. Second, we analyze the determinants of both the contractual wage levels set by collective bargaining and the wage cushion (difference between actual wages and contractual wages). ${ }^{1}$ As such, the impact of worker attributes, firm attributes, and bargaining power on actual wages is decomposed into its impact on bargained wages and on the wage cushion. The analysis, therefore, progresses to the identification of the role of institutional forces versus market forces (firmlevel arrangements) on wages.

Section II summarizes the institutional framework for wage bargaining in Portugal. Section III provides information on the data set and concepts used. Section IV presents the results on the impact of the attributes of the worker, the firm, and the bargaining process on contractual wages and on the wage cushion. Section V discusses the question of what can be learned from the empirical results about a formal model of collective bargaining, scrutinizing the existence and the impact of trade unions' egalitarian pay policies. Section VI checks the robustness of the results, and Section VII concludes.

\section{Institutional Framework for Wage Bargaining in Portugal: What Room for Firm Maneuvering?}

Portugal shares with several other European countries characteristics of a regulated industrial relations system, in contrast with the American model. Several aspects can be highlighted to support this claim.

Degree of centralization in collective bargaining. Massive collective agreements, often covering a whole industry, predominate in the economy, while firm-level collective bargaining covers a low proportion, less than $10 \%$, of the workforce. Also, centralized negotiations at the national level have been taking place each year since 1984 between trade union confederations, employers' federations, and the government. This level of bargaining sets indicative guidelines for wage increases, which shape the collective bargaining that follows.

The role of extension mechanisms. Extension mechanisms are wide-

${ }^{1}$ We thank Olivier Blanchard for having suggested the expression wage cushion to be used instead of wage drift. The difference between actual wages and contractual wages has been often referred in the literature as wage drift. Note, however, that most often such concept refers to wage changes: the difference between the total wage growth and the growth in contractual wages between two moments in time. Here, we are referring to wage levels: the difference between the total wage level and the contractual wage level at a point in time. To avoid this source of ambiguity we have therefore welcomed the suggestion to use the expression wage cushion instead. 
spread in the economy. Voluntary extensions are common, when one economic partner-workers' or employers' representative-decides to subscribe to an agreement that it had initially not signed. The agreement of the other party is required. Also, employers who sign an agreement with a trade union(s) usually extend its application to their entire workforce, irrespective of the worker's union membership status. Moreover, mandatory extensions can be applied. In this case, the contract signed does not result from direct bargaining between workers and employers, but it is instead dictated by the government (Ministry of Employment and the ministry ruling the economic sector). It can extend the applicability of an existing collective agreement to workers initially not covered by it, or it can have new original contents, if it is not feasible to extend the application of an existing document. A mandatory regime is applied when workers are not covered by unions, when one of the parties involved refuses to negotiate or bargaining is obstructed in any other way. Therefore, the impact of collective bargaining goes far beyond union membership, and the distinction between unionized and nonunionized workers or firms becomes less meaningful.

Fragmentation of the union structure may result in several agreements coexisting for the same region, occupation, economic sector, or even firm, as several unions can represent the same type of worker, depending on their affiliation. ${ }^{2}$ Legal rules solve the dubious situations that might arise, and a sensible procedure is often followed. In practice, one union usually takes the lead negotiating for a type of worker (usually the union that has the strongest bargaining power), and the others follow, either signing the same agreement or signing a separate agreement with similar contents. Legislation prescribes that in case the same group of workers might be covered by different collective bargaining agreements, the most favorable one, according to the judgment of the union that represents the highest number of workers concerned, should prevail. If no decision is reached according to the previous criterion, then the most recent agreement should be applied.

Frequency of wage adjustments and synchronization of bargaining. In Portugal, wage clauses in collective agreements are typically updated every year. Most of the contracts are published between January and April (by the Ministry of Employment), and the corresponding wage clauses apply (often retrospectively) from January to December. The negotiation of different collective agreements is usually synchronized. There are no contingent elements enabling pay changes during the contract.

Contents of the agreements. Since most collective agreements are

${ }^{2}$ Also, a firm may sign different firm-level agreements, with trade unions covering different workers. 
industry-wide, covering companies with very different sizes and economic conditions, their contents tend to be general, setting minimum working conditions, in particular, the base monthly wage for each category of workers, overtime pay, and the normal duration of work. Moreover, only a narrow set of topics is updated annually and, therefore, the contents of collective agreements is often pointed out as being too limited and immobile (see Dornelas 1999; Leitão 1999). ${ }^{3}$

Under these conditions, the links between the wage growth defined by collective agreements and the actual economic conditions prevailing at the micro (firm) level can be very loose. Whatever the minimum wage level agreed upon for each category of workers at the collective bargaining table, firms are free to pay higher wages, and they often deviate from that benchmark, adjusting it to firm-specific conditions.

As opposed to the portrait depicted by Hibbs and Locking (1996) for Sweden, where unions accurately predict wage growth beyond that set by collective bargaining and therefore fully incorporate it into central wage agreements, in Portugal projected wage growth is never considered in the wage-bargaining process. Indeed, bargaining sets wage levels and not wage changes.

\section{Data Set and Concepts Used}

\section{A. Data Set}

This study is based on a longitudinal data set matching firms and workers, which covers the population of plants with wage earners in the manufacturing and services private sector in Portugal, gathered yearly by the Ministry of Employment. Given the legally binding nature of the inquiry, the response rate is extremely high. Reported data include the firm's location, industry, employment, sales, ownership, legal setting, and the worker's gender, age, skill, occupation, schooling, date of admission into the company, monthly earnings, duration of work, as well as the mechanism of wage bargaining and the category in collective bargaining (see the appendix for details on the data). The wage variable is registered with exceptional accuracy. It is well known that employer-reported wage information is subject to less measurement error than worker-reported data. Also, the legal request for the data to be made available to every worker in a public space in the establishment contributes to its reliability, reducing measurement errors. Furthermore, the Quadros de Pessoal registry is routinely used by the inspectors of the Ministry of Employment to monitor whether the firm wage policy complies with the law.

\footnotetext{
${ }^{3}$ Dornelas (1999) points out that they seldom deal with health, hygiene, and security in the workplace; training and its impact on career progression; and social protection beyond the minimum compulsory need.
} 
Table 1

Correlation between Contractual Wages and the Mode of the Base Wage for the Worker Professional Categories

\begin{tabular}{|c|c|c|c|c|c|c|}
\hline & & & \multicolumn{4}{|c|}{ Sample Sizes } \\
\hline & \multicolumn{2}{|c|}{ Correlation } & \multicolumn{2}{|c|}{ Selected Sample } & \multicolumn{2}{|c|}{ Total Database } \\
\hline & 1998 & 1999 & 1998 & 1999 & 1998 & 1999 \\
\hline Banking & .992 & .994 & 53,291 & 54,502 & 60,922 & 63,599 \\
\hline Electric and electronic equipment & .885 & .949 & 23,951 & 29,717 & 38,832 & 42,870 \\
\hline Textiles: cotton and knitted fabrics & .834 & .768 & 52,849 & 53,240 & 72,518 & 72,407 \\
\hline
\end{tabular}

Source.-Computations based on Portugal, Ministério do Trabalho e da Segurança Social $(1998,1999)$; Portugal, Ministério do Trabalho e da Segurança Social, Direcção-Geral de Estuḑos, Estatística e Planeamento (various years).

Note. - Weight equal to the size of the professional category in the selected sample. The selected sample covers full-time wage earners in professional categories with at least 50 workers, with category and contractual wage unambiguously defined.

\section{B. Computation of the Contractual Wage}

In the Portuguese collective bargaining system, minimum contractual wages are defined for very specific job classifications. Given this fact, a large proportion of the workforce in each category will actually earn the minimum contractual wage that has been set by collective bargaining.

We have used this information to infer the contractual wage from the distribution of actual base wages for each worker category. In fact, the mode of the distribution of the base wage corresponds with remarkable accuracy to the contractual wage set by collective bargaining. To demonstrate this claim, we have extensively checked the relationship between contractual wages and the mode of the wage distribution for each worker category within each collective agreement, for a set of industries chosen a priori. Each of these industries covers a large proportion of the working population, and they have contrasting wage levels: industry.

Cotton and knitted fabric textiles is a low-wage manufacturing

Electric and electronic goods industry is a high-wage manufacturing industry.

Banking is a high-wage service industry.

The number of workers in the selected industries (see table 1) represents almost $10 \%$ of the full-time wage earners in manufacturing and services.

For this set of industries we have gathered the contractual wages for 1999 and 1998 for each worker category from the legal published documents (Boletim do Trabalho e do Emprego [Portugal, Ministério do Trabalho e da Segurança Social, Direcção-Geral de Estudos, Estatística e Planeamento, various years]) and compared them to the mode of the distribution of the actual base wage. The results can be summarized as follows: 
The correlation between the contractual wages set by collective bargaining and the mode of the base wage is very high, ranging from $99 \%$ to $77 \%$, respectively, in the banking sector and the textiles industry in 1999 (see table 1). Visual inspection of the relationship between the contractual wage and the mode of the base wage is presented in figure 1. Each circle represents one worker category, and its area is proportional to the number of workers covered. The accuracy of the modal base wage as an indicator of the bargained wage is well established.

For a very high proportion of the working population, the contractual wage set by collective bargaining is exactly equal to the mode of the distribution of the base wage. Such proportion ranges from $97 \%$ to $74 \%$, respectively, in the banking sector in 1999 and the electric and electronic equipment industry in 1998 (see fig. 2).

Following these results, throughout this article the mode of the base wage for each worker category within each collective agreement will be taken as the contractual wage for that professional category. ${ }^{4}$ Only categories that cover at least 50 workers and agreements with at least 1,000 workers will be kept in the analysis. The sample sizes are described in table A1 in the appendix.

\section{Computation of the Wage Cushion}

The wage cushion was computed as the log difference between the current actual wage and the current contractual wage (set for each worker category in a collective agreement):

$$
\text { wcusbion }_{i j k}=\log \left(\frac{w_{\text {actual }} i j k}{w b a r g}\right) \text {, }
$$

where $i$ stands for the worker, $j$ is the collective agreement, and $k$ is the worker professional category; wactual is the actual overall monthly earnings, including the base wage, tenure-related and other regularly paid

\footnotetext{
${ }^{4}$ Since the wages set by collective bargaining are binding, one other possibility to infer the bargained wage would be to consider the minimum base wage observed in the data set for each worker category. However, workers who worked less than the full month, e.g., due to sickness or because their contract started later in the month, may earn less than the bargained wage. In such a large sample of the working population, that method would be bound to capture the wrong value. Another approach has been checked, which consisted of identifying the bargained wage as the first peak in the distribution of the base wage, i.e., the first point after which the density function declined. However, this procedure is subject to the same drawbacks as the previous one. Still another approach checked consisted of computing the bargained wage as the 10 th percentile of the distribution of base wages. Computing the bargained wage as the mode of the base wage provided a more accurate value than any of these three procedures.
} 

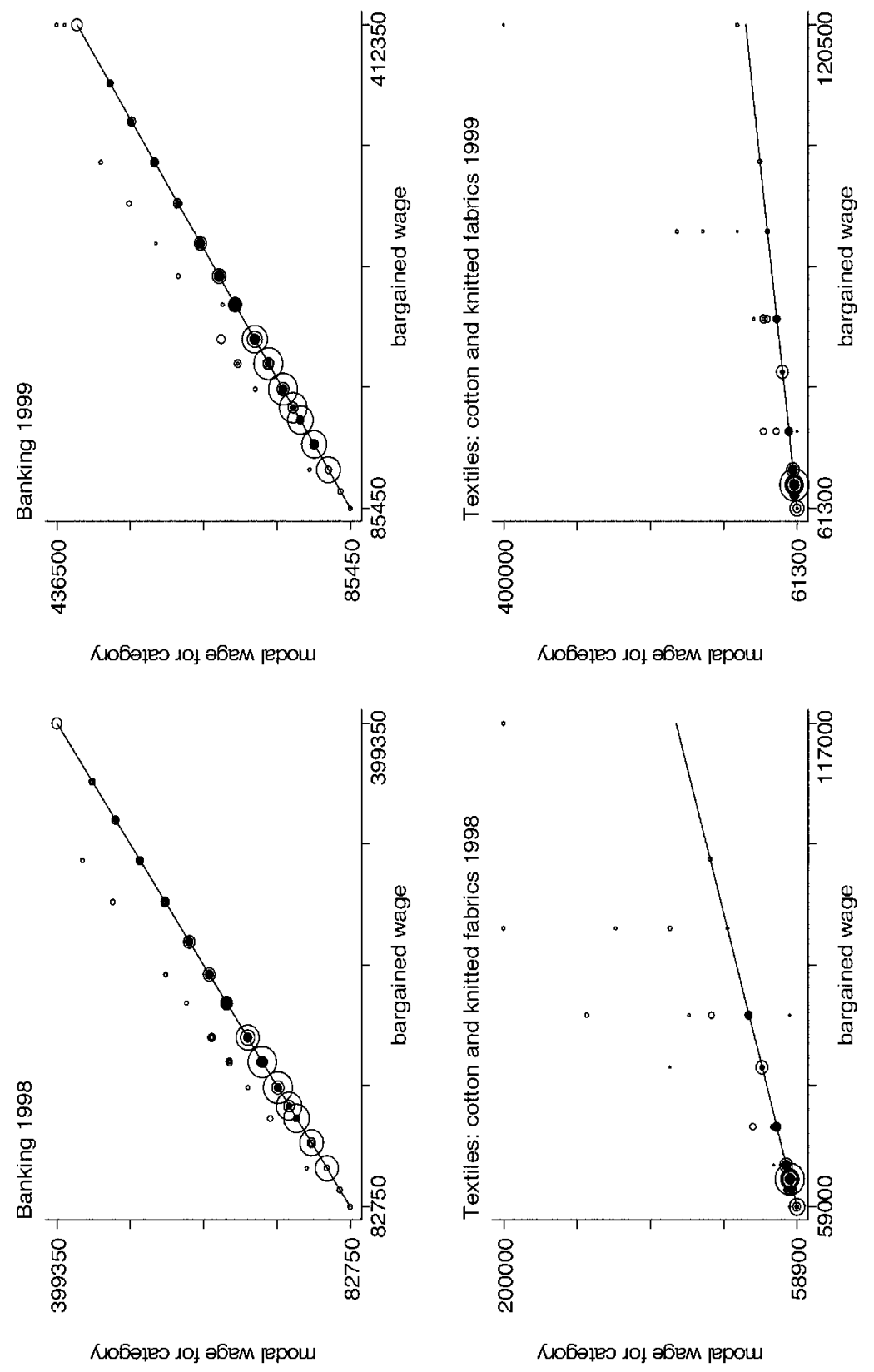

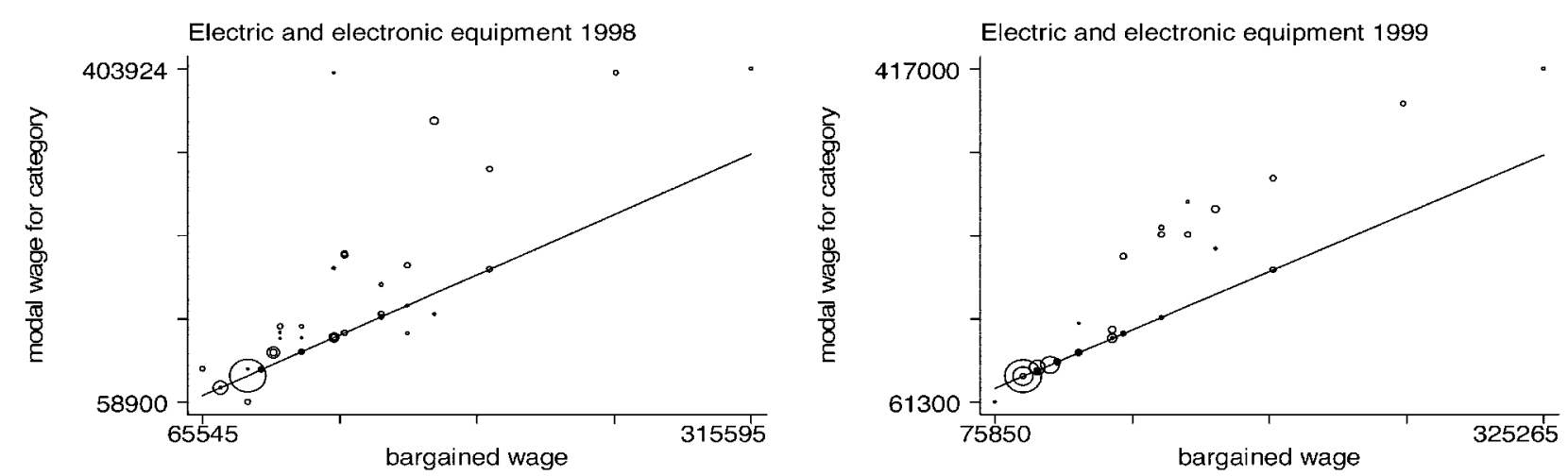

Fig. 1.-Contractual wage versus mode of the base wage by worker professional category. Each circle represents one worker professional category, and its area is proportional to the number of workers covered. Source: Computations based on Portugal, Ministério do Trabalho e da Segurança Social (1998, 1999); Portugal, Ministério do Trabalho e da Segurança Social, Direç̧ão-Geral de Estudos, Estatística e Planeamento (various years). 


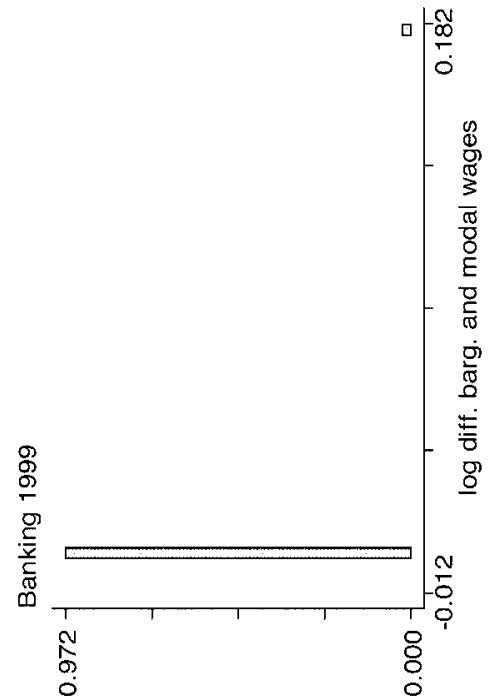

ป

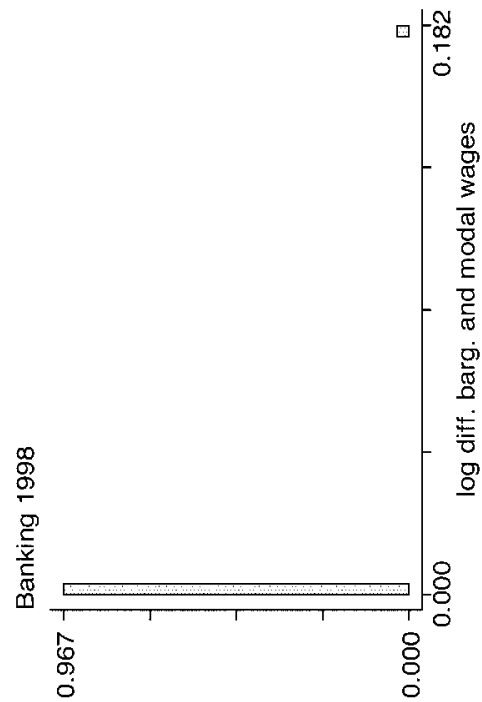

yolpex

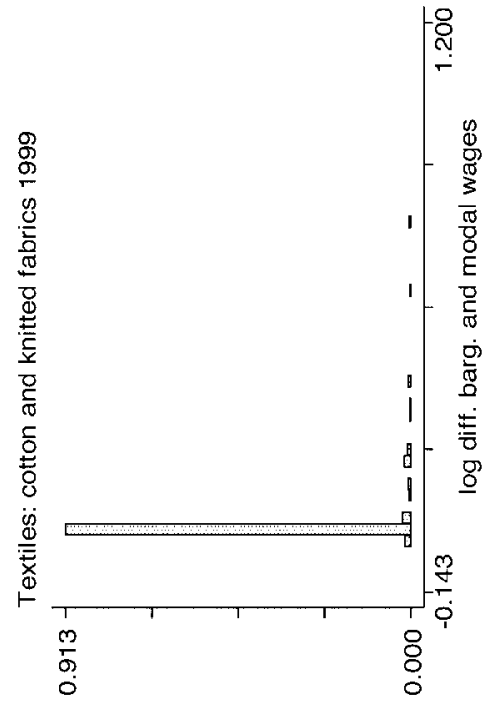

ป

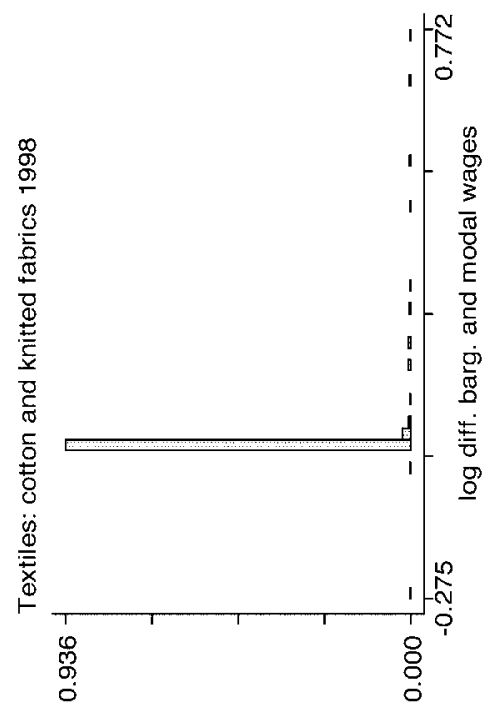

ע 
Electric and electronic equipment 1998

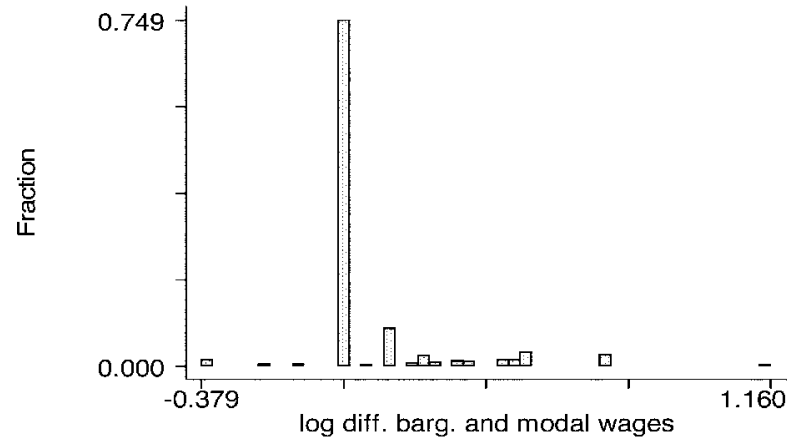

Electric and electronic equipment 1999

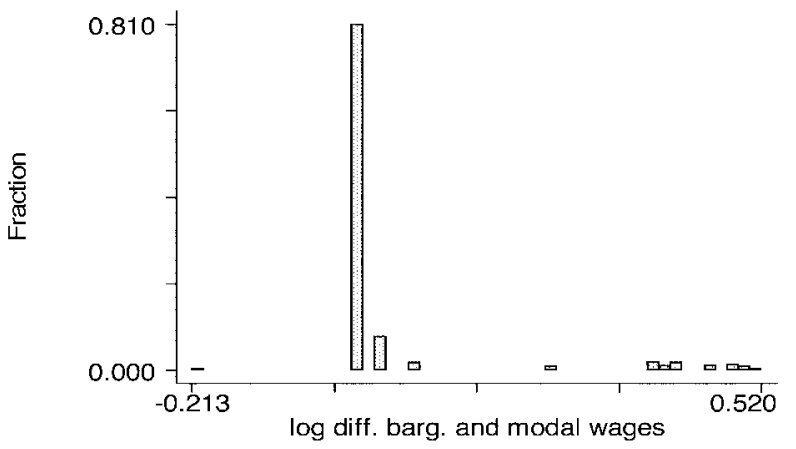

FIG. 2.- Share of workers whose contractual wage is accurately inferred using the mode of the distribution of base wages for the professional category. Source: Computations based on Portugal, Ministério do Trabalho e da Segurança Social (1998, 1999); Portugal, Ministério do Trabalho e da Segurança Social, Direcção-Geral de Estudos, Estatística e Planeamento (various years). 
Table 2

Average Wage Cushion by Industry, 1999

\begin{tabular}{lc}
\hline Industry & Average \\
\hline Food, beverages, tobacco Cushion \\
Textiles, wearing apparel, leather & .300 \\
Wood & .233 \\
Pulp, paper, printing & .265 \\
Petroleum products, chemicals, rubber, plastic & .465 \\
Other nonmetallic mineral products & .435 \\
Basic metals, fabricated metal products & .327 \\
Machinery, equipment & .326 \\
Other manufacturing & .338 \\
Electricity, gas, water supply & .241 \\
Construction & .362 \\
Trade & .298 \\
Hotels, restaurants & .383 \\
Transportation, storage, communication & .199 \\
Financial intermediation & .352 \\
Real estate, business activities & .456 \\
\hline Source.-Computations based on Portugal, Ministério do Trabalho e da Segurança Social \\
(1999).
\end{tabular}

components; and wabrg is the contractual monthly wage defined by collective bargaining. The actual wage refers to a specific month in the year (when the data are gathered), and the contractual wage is enforced throughout that year, as explained in Section II under "frequency of wage adjustments." Note that we are dealing with wage levels, and the analysis that follows focuses on the year 1999.

\section{Explaining the Contractual Wage and the Actual Wage at the Micro Level}

The average wage cushion by industry ${ }^{6}$ in 1999 ranged from 0.20 in hotels and restaurants to 0.47 in the pulp, paper, and printing industry (see table 2). As expected, the wage cushion has a de-equalizing impact on the wage distribution, as it leads to higher wage dispersion than that of bargained wages. Also according to expectations, the wage cushion is particularly heterogeneous at the top half of the distribution and more homogeneous for the lower half (see table 3 ).

Looking at the degree of association between bargained wages and the wage cushion, actual wages and their dispersion, at different levels of aggregation, yields a pattern worth mentioning (see table 4). Professional categories with higher bargained wages tend to present lower dispersion of the wage cushion (and, therefore, lower dispersion of the actual wage, since all the wage variability within a category results from the wage

${ }^{5}$ Under the expression wage drift, Ordine (1996) has also dealt with wage levels, whereas, e.g., Holden (1998) dealt with wage growth.

${ }^{6}$ Two-digit classification. 
Table 3 Dispersion of Bargained Wages, Wage Cushion, and Actual Wages, 1999

\begin{tabular}{lcccc}
\hline & Gini & Q90/Q10 & Q50/Q10 & Q90/Q50 \\
\hline Bargained wage & .228 & 2.45 & 1.25 & 1.96 \\
Wage cushion & .199 & 2.06 & 1.27 & 1.62 \\
Actual wage & .319 & 3.64 & 1.47 & 2.48 \\
\hline \multicolumn{1}{c}{ Source.-Computations based on Portugal, Ministério do Trabalho e da Seguranç Social (1999). }
\end{tabular}

Source.-Computations based on Portugal, Ministério do Trabalho e da Segurança Social (1999).

Table 4

Correlations between Bargained Wages and Actual Wage, Wage Cushion, and Their Dispersion, at Different Levels of Aggregation, 1999

\begin{tabular}{lcc}
\hline & $\begin{array}{c}\text { Professional Category } \\
\text { Bargained Wage }\end{array}$ & $\begin{array}{c}\text { Collective Agreement } \\
\text { Average Bargained } \\
\text { Wage }\end{array}$ \\
\hline Average actual wage & .901 & .949 \\
Average wage cushion & .003 & .134 \\
Dispersion of the actual wage & -.169 & -.008 \\
Dispersion of the wage cushion & -.169 & -.385 \\
\hline Source.-Computations based on Portugal, Ministério do Trabalho e da Segurança Social (1999). \\
Note.-Correlations are weighted by the size of each group. The dispersion indicator is the coefficient \\
of variation.
\end{tabular}

cushion). Similarly, at the level of the collective bargaining agreement, higher average bargained wages are associated with lower dispersion of both the wage cushion and the actual wage.

Which are the determinants of the contractual wages agreed upon with trade unions, and how do these differ from the determinants of the actual wage that is paid? Do collective bargaining outcomes reflect the bargaining power of the partners involved, whereas the wage cushion reflects market conditions?

The regressions presented in table 5 explore the impact of worker attributes, firm attributes, and the collective bargaining system on bargained wages and on the wage cushion. On the worker and employer side, the usual determinants of wages have been considered: the worker gender, schooling, age, and tenure; the firm size, age, average gross labor productivity, and its job flow. ${ }^{7}$ Controls for the industry and the region have been included in every regression.

The variables that characterize the institutional setting are less often found in the empirical literature. The degree of coordination of employers in wage bargaining and the degree of trade union power will deserve particular attention in the interpretation of the results. The degree of coordination of employers results simply from the definition of the types of collective

${ }^{7}$ Computed as $g_{f}=\Delta E_{f, 99} /\left[\frac{1}{2}\left(E_{f, 99}+E_{f, 98}\right)\right]$, where $E$ stands for employment level and $\Delta E$ for net employment change; $f$ refers to the firm. The flow of workers is computed over 1 year. 
Table 5

Determinants of Bargained Wage and the Wage Cushion (Defined Using the Total Wage) (Tobit Model)

\begin{tabular}{|c|c|c|c|c|c|c|}
\hline & \multicolumn{2}{|c|}{ Wage Bargained } & \multicolumn{2}{|c|}{ Wage Drift } & \multicolumn{2}{|c|}{ Wage Actual } \\
\hline & Coefficient & Marginal & Coefficient & Marginal & Coefficient & Marginal \\
\hline Gender & $\begin{array}{l}-.109 \\
(.0007)\end{array}$ & -.062 & $\begin{array}{l}-.128 \\
(.0007)\end{array}$ & -.079 & $\begin{array}{l}-.204 \\
(.0007)\end{array}$ & -.177 \\
\hline Schooling & $\begin{array}{l}.027 \\
(.0001)\end{array}$ & .016 & $\begin{array}{l}.030 \\
(.0001)\end{array}$ & .019 & $\begin{array}{l}.053 \\
(.0001)\end{array}$ & .047 \\
\hline Age & $\begin{array}{l}.034 \\
(.0002)\end{array}$ & .020 & $\begin{array}{l}.018 \\
(.0002)\end{array}$ & .011 & $\begin{array}{l}.038 \\
(.0002)\end{array}$ & .034 \\
\hline Age squared & $\begin{array}{l}-.0003 \\
(2.38 \mathrm{e}-06)\end{array}$ & -.0002 & $\begin{array}{l}-.0002 \\
(2.39 e-06)\end{array}$ & -.0001 & $\begin{array}{l}-.0004 \\
(2.50 \mathrm{e}-06)\end{array}$ & -.0003 \\
\hline Tenure & $\begin{array}{c}.007 \\
(1.00 \mathrm{e}-05)\end{array}$ & .004 & $\begin{array}{l}.002 \\
(.00005)\end{array}$ & .001 & $\begin{array}{l}.007 \\
(.00005)\end{array}$ & .006 \\
\hline Tenure less than 1 year & $\begin{array}{l}-.033 \\
(.0009)\end{array}$ & -.019 & $\begin{array}{c}-.038 \\
(.0009)\end{array}$ & -.024 & $\begin{array}{l}-.058 \\
(.0010)\end{array}$ & -.051 \\
\hline Firm size $(\log )$ & $\begin{array}{l}.048 \\
(.0002)\end{array}$ & .028 & $\begin{array}{l}.012 \\
(.0002)\end{array}$ & .008 & $\begin{array}{l}.041 \\
(.0002)\end{array}$ & .036 \\
\hline Firm age & $\begin{array}{l}-.0004 \\
(1.00 \mathrm{e}-05)\end{array}$ & -.0003 & $\begin{array}{l}-.0002 \\
(1.00 \mathrm{e}-05)\end{array}$ & -.0001 & $\begin{array}{c}-.0005 \\
(.00002)\end{array}$ & -.0005 \\
\hline Firm average labor productivity (log) & $\begin{array}{l}.044 \\
(.0004)\end{array}$ & .026 & $\begin{array}{l}.033 \\
(.0004)\end{array}$ & .021 & $\begin{array}{l}.064 \\
(.0004)\end{array}$ & .057 \\
\hline
\end{tabular}


Firm gross job flow rate

Agreement multifirm

Agreement sectoral

Agreement mandatory regime

Concentration agreement within occupation (Herfindhal)

Concentration agreement within firm (Herfindhal)

Concentration agreement within region (Herfindhal)

Geographic scope agreement (number regions)

Size collective agreement $(\log )$

Observations

Log likelihood

$R^{2}$
$\hat{\sigma}$

\begin{tabular}{|c|c|c|c|c|c|}
\hline $\begin{array}{l}.002 \\
(.0007)\end{array}$ & .001 & $\begin{array}{l}.012 \\
(.0007)\end{array}$ & .007 & $\begin{array}{l}.016 \\
(.0007)\end{array}$ & .014 \\
\hline $\begin{array}{l}.093 \\
(.0043)\end{array}$ & .058 & $\begin{array}{l}-.025 \\
(.0038)\end{array}$ & -.016 & $\begin{array}{r}-.017 \\
(.0044)\end{array}$ & -.015 \\
\hline $\begin{array}{l}-.036 \\
(.0031)\end{array}$ & -.022 & $\begin{array}{l}-.024 \\
(.0029)\end{array}$ & -.016 & $\begin{array}{r}-.145 \\
(.0031)\end{array}$ & -.132 \\
\hline $\begin{array}{c}-.150 \\
(.0045)\end{array}$ & -.078 & $\begin{array}{l}.179 \\
(.0041)\end{array}$ & .127 & $\begin{array}{c}-.023 \\
(.0041)\end{array}$ & -.020 \\
\hline $\begin{array}{l}.112 \\
(.0010)\end{array}$ & .065 & $\begin{array}{l}-.092 \\
(.0010)\end{array}$ & -.058 & $\begin{array}{l}-.025 \\
(.0011)\end{array}$ & -.022 \\
\hline $\begin{array}{l}.263 \\
(.0037)\end{array}$ & .153 & $\begin{array}{l}-.214 \\
(.0034)\end{array}$ & -.135 & $\begin{array}{l}-.013 \\
(.0034)\end{array}$ & -.011 \\
\hline $\begin{array}{l}-.032 \\
(.0096)\end{array}$ & -.019 & $\begin{array}{l}-.063 \\
(.0096)\end{array}$ & -.040 & $\begin{array}{l}-.183 \\
(.0102)\end{array}$ & -.161 \\
\hline $\begin{array}{l}-.005 \\
(.0001)\end{array}$ & -.003 & $\begin{array}{l}.010 \\
(.0001)\end{array}$ & .006 & $\begin{array}{l}.002 \\
(.0001)\end{array}$ & .002 \\
\hline $\begin{array}{l}-.035 \\
(.0005)\end{array}$ & -.021 & $\begin{array}{l}.008 \\
(.0005)\end{array}$ & .005 & $\begin{array}{c}-.008 \\
(.0005)\end{array}$ & -.007 \\
\hline 27 & & $1,134,427$ & & $1,134,427$ & \\
\hline 40.9 & & $-362,584.8$ & & $-372,350.1$ & \\
\hline .54 & & .30 & & .59 & \\
\hline .301 & & .312 & & .327 & \\
\hline
\end{tabular}

SourCE. - Computations based on Portugal, Ministério do Trabalho e da Segurança Social $(1998,1999)$.

NoтE.-Three regional dummy variables and 15 industry dummy variables have been included in each regression. Robust standard errors are in parentheses. 
agreements existing in Portugal: single-firm agreement; multifirm agreement, signed by several employers, though not organized into a formal association; and sector agreement, signed between employers' association(s) and trade union(s), often covering an economic sector. Also, the government can impose a mandatory regime, as described in Section II.

The degree of union bargaining power is captured by the concentration of bargaining within an occupation, firm, or region. These proxies are based on the idea that, if the labor force is more united in the bargaining process, it will have stronger bargaining power. Recent experimental evidence in Berninghaus, Guth, and Keser (2003) indeed indicates that, when opting for collective bargaining instead of decentralized bargaining, united players raise their claim for a share of the pie (even though their payoff might not be larger, if the occurrence of conflicts increases), and the opponent lowers its claims. The Herfindhal index was used to evaluate the degree of concentration of bargaining within an occupation, firm, or region. ${ }^{8}$ If one single collective agreement covers the entire workforce in the occupation, the firm, or the region, the index reaches the value one, interpreted as a high degree of union power within that occupation, firm, or region. On the contrary, a fragmented bargaining process, with workers represented by several trade unions bargaining separately, leads to a low value on the Herfindhal index and suggests less union strength.

We have estimated tobit models on the wage bargained, the wage cushion, and, a result of the two previous forces, the actual wages paid. This choice is justified by the fact that contract wages cannot fall below the national minimum wage and actual wages cannot fall below the contract wage defined for the worker category.

It is interesting to note, first of all, that the wage cushion reinforces the impact of worker and firm attributes on wages (table 5). Note that the signs of those coefficients are the same, in the bargained wage and the wage cushion regressions. In other words, the wage cushion stretches the returns to education, gender, age, tenure, firm size, firm productivity, or firm-level worker turnover (rate of job creation or destruction). On the contrary, variables that capture the bargaining power of trade unions have a high impact on bargained wages, but that impact is partly offset by the wage cushion. In fact, the concentration of bargaining within an occupation or within a firm becomes less relevant in the determination of actual wages than it was in the determination of bargained wages. In other words, the wage cushion shrinks the returns to union bargaining power. The previous results lend support to the hypothesis that the wage

${ }^{8}$ It is computed as $H_{u}=\sum_{j}\left(\text { share }_{j u}\right)^{2}$, where share $_{j u}$ is the share of workers covered by collective agreement $j$, within unit $u$ (defined as an occupation at the four-digit level, yielding 402 occupations; a firm; or a region, defined at a detailed level, yielding 18 regions in mainland Portugal). 
cushion works as a mechanism to overcome the constraints imposed by collective bargaining, allowing firms wide scope for action in their wage policy.

The impact of the extent of union power deserves further comment. Higher coordination on the side of the workers along occupation or firm lines is associated with higher wages. If the degree of concentration of bargaining within an occupation increases by 10 percentage points, the bargained wage increases by about $1 \%$. Similarly, a more united labor force bargaining within the firm raises bargained wages: an increase of 10 percentage points in the degree of concentration of bargaining within a firm raises bargained wages by approximately $2 \%$. These results suggest that the fragmentation of bargaining reduces union capacity to extract rents.

However, as mentioned before, these returns on union bargaining power are offset by firm-specific wage arrangements, in the form of wage cushion. In the end, the concentration of bargaining within the occupation or the firm has a very low impact on the actual wages paid.

The interpretation of the results on the geographical coverage of the agreements is not as clear-cut. On the one hand, agreements covering a wider area are associated with lower bargained wages, possibly because unions are in that case unable to fully exploit local labor market conditions. On the other hand, as opposed to the results for the occupation and firm, more fragmented wage bargaining within the region leads to higher wage settlements, a result that is reinforced by the wage cushion.

On the employer side, higher coordination when bargaining over wages is associated with lower wages. Single-firm or multifirm agreements yield higher bargained wages than sector-level agreements. Even though the rank of the type of agreement changes after the wage cushion operates, it is still the case that single-firm and multifirm agreements yield higher wages than sector agreements. These results lend support to the reasoning by Nickell (1997), according to which the coordination of employers leads to lower bargained wages, reducing the impact of collective bargaining on unemployment.

The positive impact of the firm's rate of job creation and its average labor productivity on the bargained wage is consistent with the results by Christofides and Oswald (1992), who analyzed the impact of industry and regional variables on wages bargained in a sample of labor contracts in Canada and found evidence that wage determination is a rent-sharing mechanism. Their work found that higher profits in the industry enable unions to extract a higher rent in the form of higher bargained wages, whereas a depressed labor market, with a higher regional unemployment rate, decreases bargained wages.

To further check the adequacy of the procedure used to compute the bargained wage, we have replicated the regressions presented using only 
the three industries described in Section III.B and two alternative concepts of bargained wage: (a) the true bargained wage set in the collective contract and $(b)$ our proxy, the mode of the base wage for each contract and worker category. The results obtained are very similar, indeed, revealing that they are robust to our choice of proxy for the wage bargained. ${ }^{9}$

\section{What Can Be Learned from the Empirical Results about a Formal Model of Collective Bargaining?}

The results so far presented are compatible with two different situations in terms of trade union action and formal models of bargaining. On the one hand, it could be the case that trade unions in Portugal have low bargaining power, being unable to extract a high return on worker attributes. Willingness of companies to pay a higher wage premium would thus be revealed only after the stage of collective bargaining, in the form of wage cushion operating at the firm level. On the other hand, it could be the case that unions, though having high bargaining power, have strong equalizing aims, explicitly trying to compress the returns to worker attributes. As such, they would use their bargaining power to set a higher overall wage level, but a lower return on worker attributes.

Several empirical studies using cross-section worker data have indeed shown that trade unions reduce wage dispersion, in particular because the returns to worker attributes are lower in the unionized sector (Freeman 1980; Meng 1990; Fairris 2003), just like the returns to firm attributes (Dell'Aringa and Lucifora 1994). However, the impact of union action on wages could partly result from selectivity, if the worker unobservable quality is correlated with the unionization status, a problem that can only be tackled using longitudinal data. Longitudinal studies may, however, underestimate the impact of trade unions on wages, if there is measurement error in the variable union status (Freeman 1984). Explicitly accounting for selectivity and measurement error in union status, Card (1996) showed that unions compress the wage distribution by raising more the wages of low-skilled workers. Part of this result is driven by a selection mechanism: union members with low observable skills have higher unobservable quality than non-union members; conversely, union members with high observable skills have lower unobservable quality than non-union members. Lemieux (1998) allowed the returns to worker observable attributes and unobservable quality to differ in the unionized and nonunionized sectors. Interestingly, he finds that unions raise the average wage level but compress the returns to both observable and unobservable worker quality. The finding by the empirical literature that unions

${ }^{9}$ Tables with the results of that comparison can be obtained from the authors upon request. 
reduce wage dispersion, in particular by lowering the returns on human capital, therefore seems robust.

Theoretical models explicitly handling the role of wage dispersion in union preferences are, however, scarcer. The models by Farber (1978) and Booth (1984) handle trade unions' egalitarian aims by considering that they are political units, whose policies will determine workers' support for the union leaders or their membership decision. As such, union leaders will choose to bargain for the wage that maximizes the utility of the median voter. If the median wage is below the mean wage, as is commonly the case, a majority of workers will favor a policy that compresses the wage distribution. According to Agell and Lommerud (1992), there is an insurance rationale for wage compression. If risk-averse workers face uncertainty about their future position in the wage distribution, and the market fails to provide insurance against wage risks, then workers will support wage compression. Rodríguez-Gutiérrez (2001) directly introduces the degree of wage dispersion into the union utility function, based on the assumption that unions obtain utility from wage compression.

The two hypotheses put forth to explain the results on Portugal-the existence of a low union bargaining power or an explicit aim by unions to reduce the returns on worker attributes-can be disentangled, within the framework of the current article, by running the previous regression of bargained wages with interaction terms between every worker attribute and a measure of union power (the concentration of bargaining within occupations) among the regressors. The coefficients on those interaction terms would enable an answer to the question, Do trade unions use their bargaining power to lower the returns on worker attributes while, nevertheless, raising the overall wage level?

The results in table 6 provide support for the egalitarian pay policy hypothesis. They show that trade unions use their power to raise the overall wage level (see the coefficients on the concentration of bargaining within the occupation or firm) and to reduce the wage penalty imposed on women and newcomers into the firm (see the positive coefficients on the interactions of each of these variables with the index of trade union power). On the contrary, a higher union bargaining power is associated with lower returns on schooling, age, and tenure. The low returns to worker attributes set by collective bargaining do not result from a lack of union power but, instead, from an explicit aim of compressing the wage distribution, while raising the overall wage level.

\section{Checking the Robustness of the Results}

The components of pay considered in actual wages could bear on the findings and interpretation of the results. Whereas most agreements address specifically the base monthly wage, overtime pay, and the normal 
Table 6

Determinants of Bargained Wages (Tobit Model): Worker Attributes Interacted with Degree of Union Power, 1999

\begin{tabular}{|c|c|c|c|}
\hline Variable & Coefficient & Robust SE & Marginal \\
\hline Gender & -.113 & .0010 & -.065 \\
\hline Schooling & .032 & .0002 & .018 \\
\hline Age & .044 & .0003 & .026 \\
\hline Age squared & -.0004 & .0000 & -.0003 \\
\hline Tenure & .010 & .0001 & .006 \\
\hline Tenure less than 1 year & -.036 & .0015 & -.021 \\
\hline Gender $\times$ union power & .016 & .0019 & .009 \\
\hline Schooling $\times$ union power & -.015 & .0003 & -.009 \\
\hline Age $\times$ union power & -.027 & .0005 & -.016 \\
\hline Age squared $\times$ union power & .0004 & .0000 & .0002 \\
\hline Tenure $x$ union power & -.009 & .0001 & -.005 \\
\hline Tenure less than 1 year $\times$ union power & .026 & .0025 & .015 \\
\hline Firm size $(\log )$ & .049 & .0002 & .028 \\
\hline Firm age & -.001 & .0000 & -.0003 \\
\hline Firm average labor productivity (log) & .043 & .0004 & .025 \\
\hline Firm gross job flow rate & .0002 & .0007 & -.0001 \\
\hline Agreement multifirm & .109 & .0043 & .069 \\
\hline Agreement sectoral & -.037 & .0031 & -.022 \\
\hline Agreement mandatory regime & -.144 & .0046 & -.075 \\
\hline \multicolumn{4}{|l|}{ Concentration agreement within occupation } \\
\hline (Herfindhal) & .839 & .0099 & .489 \\
\hline Concentration agreement within firm (Herfindhal) & .257 & .0037 & .150 \\
\hline \multicolumn{4}{|l|}{ Concentration agreement within region } \\
\hline (Herfindhal) & -.011 & .0095 & -.006 \\
\hline Geographic scope agreement (number regions) & -.005 & .0001 & -.003 \\
\hline Size collective agreement $(\log )$ & -.036 & .0005 & -.021 \\
\hline Observations & & $1,134,427$ & \\
\hline Log likelihood & & $-395,033.5$ & \\
\hline$R^{2}$ & & .55 & \\
\hline$\hat{\sigma}$ & & .299 & \\
\hline
\end{tabular}

duration of work, some handle other regularly paid components of wage, such as tenure-related payments. As such, trade unions might have some control over the wage cushion computed (since it includes those components), in which case it would not be strictly an employer-driven adjustment. Two different procedures have been followed to evaluate the extension of this problem.

We have first of all replicated the computations previously presented, considering just the cushion in base wages (instead of regular wages, which included tenure and other regular payments). The results in table 7, consistent with the results previously reported, indicate that the wage cushion reinforces the returns to worker attributes set in collective bargaining; on the contrary, variables that capture the bargaining power of trade unions have a high impact on bargained wages, but that impact is partly offset by the wage cushion. Note that, since bargained wages remain unchanged 
in these computations, it is still the case that low returns to worker attributes set by collective bargaining are a result of the egalitarian pay policy followed and not a result of low union bargaining power.

This procedure, nevertheless, highlights an interesting difference between different types of contracts. For massive wage-setting agreements (sector level or mandatory extensions), the wage cushion operates mainly on base wages (table 8 provides descriptive statistics clarifying this point, which show that in single-firm and multifirm agreements, the wage cushion operates mainly through regularly paid components, whereas in sector and mandatory agreements it operates mainly on base wages). Therefore, whereas the impact of employer coordination on bargained wages remains unchanged (less coordination, in single-firm and multifirm agreements, yields higher bargained wages), the impact on final wages is not as clearcut. When only actual base wages are considered, the mandatory regime exhibits, ceteris paribus, higher wage cushion.

Second, we have checked the hypothesis pointed out by Freeman and Medoff (1979), according to which trade unions, though equalizing base wages based on personal attributes, de-equalize fringe benefits and other payments based on seniority (in particular, deferred compensation). This was accomplished by running a regression of the wage cushion with interaction terms between every worker attribute and a measure of union power. The results (in table 9) show that, also at the level of the wage cushion, higher union power is associated with lower returns on education and age, an indication of the egalitarian aims pursued. However, trade union power raises the returns to tenure (the impact of tenure on wages now operates only through union power, as the major effect becomes insignificant). ${ }^{10}$

\section{Conclusion}

Most often, micro level analysis of the returns to worker and firm attributes have considered only the actual wage of the worker. This study has progressed along two directions. First of all, we have decomposed

\footnotetext{
${ }^{10}$ Differences across bargaining regimes have also been explored. Running a separate regression for each regime mainly highlights that firm-level agreements stand apart from the other regimes: the influence of firm conditions at the bargaining stage is most pronounced in firm-level agreements, a result that fits expectations; also at the bargaining stage, firm-level agreements provide returns to schooling that are higher than those for any other regime; for every regime, the wage cushion reinforces the returns to worker attributes that had been set in the bargaining contract (the notable exception being that in firm-level agreements the high returns to schooling and the tough penalty on newcomers set when bargaining are partly offset by the wage cushion); for massive wage contracts (sector or mandatory regime), the wage cushion increases sharply the returns to schooling and experience/age (the full set of results is available from the authors upon request).
} 
Table 7

Determinants of Bargained Wage and the Wage Cushion (Defined Using Just the Base Wage instead of Total Wage) (Tobit Model)

\begin{tabular}{|c|c|c|c|c|c|c|}
\hline & \multicolumn{2}{|c|}{ Bargained Wage } & \multicolumn{2}{|c|}{ Wage Cushion } & \multicolumn{2}{|c|}{ Actual Wage } \\
\hline & Coefficient & Marginal & Coefficient & Marginal & Coefficient & Marginal \\
\hline Gender & $\begin{array}{c}-.109 \\
(.001)\end{array}$ & -.062 & $\begin{array}{c}-.141 \\
(.001)\end{array}$ & -.100 & $\begin{array}{c}-.191 \\
(.001)\end{array}$ & -.146 \\
\hline Schooling & $\begin{array}{l}.027 \\
(.000)\end{array}$ & .016 & $\begin{array}{l}.04 \\
(.000)\end{array}$ & .031 & $\begin{array}{l}.056 \\
(.000)\end{array}$ & .044 \\
\hline Age & $\begin{array}{l}.034 \\
(.000)\end{array}$ & .02 & $\begin{array}{c}.024 \\
(.000)\end{array}$ & .016 & $\begin{array}{l}.042 \\
(.000)\end{array}$ & .033 \\
\hline Age squared & $\begin{array}{r}-.0003 \\
(.000)\end{array}$ & .000 & $\begin{array}{r}-.0002 \\
(.000)\end{array}$ & .000 & $\begin{array}{r}-.0004 \\
(.000)\end{array}$ & .000 \\
\hline Tenure & $\begin{array}{c}.007 \\
(.000)\end{array}$ & .004 & $\begin{array}{c}.002 \\
(.000)\end{array}$ & .001 & $\begin{array}{c}.007 \\
(.000)\end{array}$ & .005 \\
\hline Tenure $<1$ year & $\begin{array}{c}-.033 \\
(.001)\end{array}$ & -.019 & $\begin{array}{c}-.053 \\
(.001)\end{array}$ & -.029 & $\begin{array}{c}-.061 \\
(.001)\end{array}$ & -.046 \\
\hline Firm size $(\log )$ & $\begin{array}{c}.048 \\
(.000)\end{array}$ & .028 & $\begin{array}{c}-.01 \\
(.000)\end{array}$ & -.005 & $\begin{array}{c}.029 \\
(.000)\end{array}$ & .023 \\
\hline Firm age & $\begin{array}{c}-.004 \\
(.000)\end{array}$ & .000 & $\begin{array}{l}.001 \\
(.000)\end{array}$ & .000 & $\begin{array}{r}-.0002 \\
(.000)\end{array}$ & .000 \\
\hline
\end{tabular}


Firm average labor productivity

Firm gross job flow rate

Agreement multifirm

Agreement sector

Agreement mandatory regime

Concentration agreement within occupation (Herfindhal)

Concentration agreement within firm (Herfindhal)

Concentration agreement within region (Herfindhal)

Geographic scope agreement

Size collective agreement $(\log )$

Observations

Log likelihood

SOURCE. - Computations based on Portugal, Ministério do Trabalho e da Segurança Social (1998, 1999).

SOURCE. - Computations based on Portugal, Ministério do Trabalho e da Segurança Social $(1998,1999)$.
NOTE. - Three regional dummy variables and 15 industry dummy variables have been included in each regression. Robust standard errors are in parentheses.

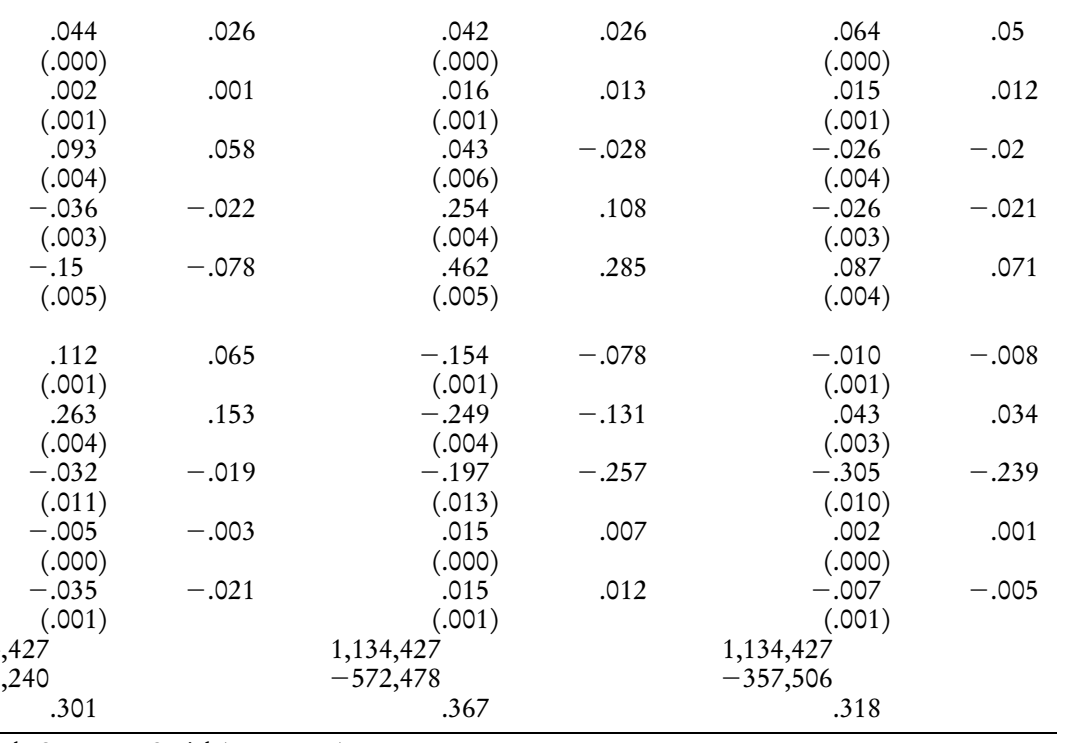


Table 8

Mean Wage Cushion for Base Wage and Regularly Paid

\section{Compensation}

\begin{tabular}{lcc}
\hline & \multicolumn{2}{c}{ Concept of Actual Wage } \\
\cline { 2 - 3 } $\begin{array}{l}\text { Bargaining } \\
\text { Regime }\end{array}$ & Base Wage & All Regularly Paid Compensation \\
\hline Firm & 1.02 & 1.44 \\
Multifirm & 1.07 & 1.61 \\
Sector & 1.28 & 1.46 \\
Mandatory & 1.94 & 2.15 \\
\hline SourCE.-Computations based on Portugal, Ministério do Trabalho e da Segurança \\
Social (1999). \\
NotE.-wcushion = actualwage/bargwage.
\end{tabular}

Table 9

Determinants of the Wage Cushion (Tobit Model): Worker Attributes Interacted with Degree of Union Power, 1999

\begin{tabular}{|c|c|c|c|}
\hline & Coefficient & Robust SE & Marginal \\
\hline Gender & -.135 & .001 & -.083 \\
\hline Schooling & .034 & .000 & .021 \\
\hline Age & .022 & .000 & .014 \\
\hline Age squared & .00 & .000 & .00 \\
\hline Tenure & .000 & .000 & .00 \\
\hline Tenure $<1$ year & -.047 & .001 & -.029 \\
\hline Gender $\times$ union power & .019 & .002 & .012 \\
\hline Schooling $\times$ union power & -.013 & .000 & -.008 \\
\hline Age $\times$ union power & -.014 & .001 & -.009 \\
\hline Age squared $\times$ union power & .000 & .000 & .000 \\
\hline Tenure $\times$ union power & .004 & .000 & .003 \\
\hline Tenure $<1$ year $\times$ union power & .029 & .003 & .019 \\
\hline Firm size $(\log )$ & .012 & .000 & .008 \\
\hline Firm age & .000 & .000 & .000 \\
\hline Firm average labor productivity & .033 & .000 & .021 \\
\hline Firm gross job flow rate & .011 & .001 & .007 \\
\hline Agreement multifirm & -.024 & .004 & -.015 \\
\hline Agreement sector & -.024 & .003 & -.016 \\
\hline Agreement mandatory regime & .179 & .004 & .127 \\
\hline \multicolumn{4}{|l|}{ Concentration agreement within occupation } \\
\hline Concentration agreement within firm (Herfindhal) & -.215 & .003 & -.136 \\
\hline \multicolumn{4}{|l|}{ Concentration agreement within region } \\
\hline (Herfindhal) & -.055 & .010 & -.035 \\
\hline Geographic scope agreement & .010 & .000 & .006 \\
\hline Size collective agreement $(\log )$ & .008 & .001 & .005 \\
\hline Observations & $1,134,427$ & & \\
\hline Log likelihood & $-360,686$ & & \\
\hline$\hat{\sigma}$ & .312 & & \\
\hline
\end{tabular}


the worker's actual wage into the wage set by collective bargaining and firm-specific wage arrangements, in the form of the wage cushion. Second, we have analyzed the impact on wages of not just worker and firm attributes but also characteristics of the wage-setting process. In particular, we focused on the impact of union bargaining power and the degree of employer coordination on the wage distribution.

We found that the distribution of wages set by collective agreements reflects to a high extent the bargaining power of the partners negotiating; as such, higher coordination among employers tends to be associated with lower wages, whereas a more united labor force bargaining within an occupation or firm raises the overall wage level, while reducing the returns to worker attributes, an indication of the strong equalizing aims pursued by trade unions. However, the wage cushion works as a mechanism to overcome the constraints imposed by collective bargaining, allowing firms wide scope for action in their wage-setting policy. Indeed, the wage cushion reinforces the impact of worker and firm attributes on wages while, on the contrary, it dilutes the impact of collective bargaining. The wage cushion stretches the returns to education, gender, age, tenure, firm size, firm age, and firm productivity, whereas, on the contrary, it shrinks the returns to union bargaining power. This operation of institutional forces and market forces in the Portuguese economy may help explain why a typically European institutional framework is compatible with high wage flexibility and low unemployment.

\section{Appendix}

\section{Data Set}

Quadros de Pessoal gathers information on workers, firms, and collective bargaining contracts in the Portuguese private sector. The data are gathered yearly by the Ministry of Employment. All workers employed in the firm in a reference week each year are reported (as such, they do not have to be full-year workers). In this study, only full-time wage earners working at least 25 hours a week, ages $16-65$, earning at least the national minimum wage, in manufacturing and services in mainland Portugal, were considered for analysis. The national minimum wage constraint may drop workers in particular categories, such as apprentices and youngsters below the age of 18.

Given that we are computing the bargained wage as the mode of the distribution of base wages for each category of workers, the categories considered in the analysis should cover a certain number of workers. Categories with at least 50 workers and agreements with at least 1,000 workers were kept for analysis.

The database reports the gross monthly wage, split into the following components: base wage, seniority-indexed components of pay, other reg- 
ularly paid components, overtime work, and irregularly paid components. Normal and overtime hours of work are reported as well. Minimum contractual wages are defined in Portugal as a monthly wage rate.

Table A1

Sample Sizes in the Analysis of Wage Bargained and Wage Cushion, 1999

\begin{tabular}{|c|c|c|c|c|}
\hline Sample Size & Workers & Firms & Agreements & Categories \\
\hline $\begin{array}{l}\text { Total employer-employee data set } \\
\text { Full-timers. } 16-65 \text { vears }\end{array}$ & $2,568,456$ & 242,026 & 531 & 30,659 \\
\hline $\begin{array}{l}\text { Full-timers, } 16-65 \text { years, manufac- } \\
\text { turing and service, } w \geq \text { min } \\
\text { Collective bargaining categories }\end{array}$ & $1,644,550$ & 172,372 & 385 & 24,114 \\
\hline $\begin{array}{l}\geq 50 \text { workers } \\
\text { Collective bargaining agreements }\end{array}$ & $1,462,932$ & 165,795 & 232 & 3,871 \\
\hline$\geq 1,000$ workers & $1,438,699$ & 162,604 & 133 & 3,662 \\
\hline
\end{tabular}

Table A2

Descriptive Statistics, Regression Data, 1999

\begin{tabular}{lcc}
\hline Variable & Mean & SD \\
\hline Bargained wage (log) & 11.35 & .38 \\
Wage cushion (log) & .33 & .33 \\
Gender & .4 & \\
Schooling & 7.34 & 3.81 \\
Age & 36.08 & 11.07 \\
Tenure & 7.86 & 8.80 \\
Tenure less than 1 year & .17 & \\
Firm size (log) & 4.53 & 2.37 \\
Firm age & 21.63 & 23.5 \\
Firm average labor productivity (log) & 9.17 & 1.24 \\
Firm gross job flow rate & .15 & .5 \\
Agreement multifirm & .05 & \\
Agreement sectoral & .86 & \\
Agreement mandatory regime & .04 & \\
Concentration agreement within individual & & \\
$\quad$ (Herfindhal) & .69 & .3 \\
Concentration agreement within firm (Herfindhal) & .97 & .1 \\
Concentration agreement within region (Herfindhal) & .07 & .04 \\
Geographic scope agreement (number regions) & 14.51 & 5.25 \\
Size collective agreement (log) & 10.38 & 1.24 \\
$N$ & \multicolumn{2}{c}{$1,134,427$} \\
\hline Source.-Computations based on Portugal, Ministério do Trabalho e da Segurança Social (1998, \\
1999). & &
\end{tabular}

\section{References}

Agell, Jonas, and Kjell Erik Lommerud. 1992. Union egalitarianism as income insurance. Economica 59, no. 235:295-310.

Berninghaus, Siegfried, Werner Guth, and Claudia Keser. 2003. Unity suggests strength: An experimental study of decentralized and collective bargaining. Labour Economics 10, no. 4:465-79. 
Booth, Alison. 1984. A public choice model of trade union behaviour and membership. Economic Journal 94, no. 376:883-98.

Calmfors, Lars, and John Driffill. 1988. Centralization of wage bargaining. Economic Policy 6:13-47.

Card, David. 1996. The effect of unions on the structure of wages: A longitudinal analysis. Econometrica 64, no. 4:957-79.

Christofides, Louis N., and Andrew J. Oswald. 1992. Real wage determination and rent-sharing in collective bargaining agreements. Quarterly Journal of Economics 107, no. 3:985-1002.

Dell'Aringa, Carlo, and Claudio Lucifora. 1994. Wage dispersion and unionism: Do unions protect low pay? International Journal of Manpower 15, nos. 2/3:150-69.

Dornelas, António. 1999. As relações industriais em Portugal: É possível mudar? É possível não mudar? [Industrial relations in Portugal: Is it possible to change? Is it possible not to change?] Sociedade e Trabalho 7:19-28.

Fairris, David. 2003. Unions and wage inequality in Mexico. Industrial and Labor Relations Review 56, no. 3:481-97.

Farber, Henry S. 1978. Individual preferences and union wage determination: The case of the United Mine workers. Journal of Political Economy 86, no. 5:923-42.

Freeman, Richard B. 1980. Unionism and the dispersion of wages. Industrial and Labor Relations Review 34, no. 1:3-23.

. 1984. Longitudinal analyses of the effects of trade unions. Journal of Labor Economics 2, no. 1:1-26.

Freeman, Richard B., and James L. Medoff. 1979. The two faces of unionism. Public Interest 57:69-93.

Hartog, Joop, Edwin Leuven, and Coen Teulings. 2002. Wages and the bargaining regime in a corporatist setting: The Netherlands. European Journal of Political Economy 18:317-31.

Hartog, Joop, Pedro T. Pereira, and José A. C. Vieira. 2002. Bargaining regimes and wages in Portugal. Portuguese Economic Journal 1, no. 3: 237-58.

Hibbs Jr., Douglas A., and Hakan Locking. 1996. Wage compression, wage drift and wage inflation in Sweden. Labour Economics 3:109-41.

Holden, Steinar. 1998. Wage drift and the relevance of centralised wage setting. Scandinavian Journal of Economics 100:711-31.

Leitão, Maria Josefina Menezes. 1999. Traços gerais da contratação colectiva em Portugal [General characteristics of collective bargaining in Portugal]. Sociedade e Trabalho 4:19-28.

Lemieux, Thomas. 1998. Estimating the effects of unions on wage inequality in a panel data model with comparative advantage and nonrandom selection. Journal of Labor Economics 16, no. 2:261-91. 
Meng, Ronald. 1990. Union effects on wage dispersion in Canadian industry. Economics Letters 32:399-403.

Nickell, Stephen. 1997. Unemployment and labor market rigidities: Europe versus North America. Journal of Economic Perspectives 11, no. 3:55-74.

OECD (Organisation for Economic Co-operation and Development). 1992. OECD Economic Surveys, Portugal, 1991/92. Paris: OECD.

Ordine, Patrizia. 1996. Wage drift and minimum contractual wage: Theoretical interrelationship and empirical evidence for Italy. Labour Economics 2:335-57.

Portugal, Ministério do Trabalho e da Segurança Social. 1998. Quadros de Pessoal. Data in magnetic media. Lisbon: MTSS.

1999. Quadros de Pessoal. Data in magnetic media. Lisbon: MTSS.

Portugal, Ministério do Trabalho e da Segurança Social, Direcção-Geral de Estudos, Estatística e Planeamento. Various years. Boletim do Trabalho e Emprego. Lisbon: MTSS.

Rodríguez-Gutiérrez, César. 2001. Wage dispersion within firms and collective bargaining in Spain. Economics Letters 72:381-86.

Teulings, Coen, and Joop Hartog. 1998. Corporatism or competition? Cambridge: Cambridge University Press. 